research, Isoniazid remains to this day the only effective anti-tuberculous drug without serious side effects.

A book in which the theory and practice of antituberculous chemotherapy is discussed by acknowledged experts is of the greatest value to all chest physicians. Of the ten chapters in this volume eight are devoted to chemistry and bacteriology leaving only the last 50 pages to the clinical applications. The two final chapters on "Clinical Evaluation" by Crofton and on "The Current Status of Chemotherapy" by Bignall, are however so comprehensive that they silence any criticism of a possible lack of balance between theory and practice. No other book or review article contains so much useful information about these drugs. The list of references is excellent. Only the most recent work on substitutes for P.A.S. and on trials with second line drug combinations is missing but this was no doubt unavoidable.

The first part will appeal to bacteriologists, the final chapters to physicians, though even the most clinically minded reader will find much of interest in the earlier chapters on the mode of action of drugs and the evaluation of drug resistant strains. Both bacteriologists and chest physicians may well decide to adopt this book as a standard work of reference.

\section{The Physiology of Human Pregnancy}

Frank E. Hytten and Isabella Leitch. Pp. xii + 463. Oxford: Blackwell Scientific Publications. 1964. 55s.

This book, packed with facts and theories about the normal changes that occur in the pregnant woman's body, must replace for the post-graduate examination student those individual chapters in standard textbooks from which he would normally gain his knowledge. More reading, more research and more thought than any clinician could possibly ever have the time to gather for himself, has gone into the collection and collation of information about such matters as the cardiovascular and respiratory systems of the mother and her foetus, weight gain and diet, incidence of multiple births, sex ratios at different ages, renal and alimentary factors and hormone changes.

This is the book's strength and at the same time its weakness. It presents its invaluable information, in such a way that a practitioner feels that, although he has been told all the ways in which blood volume changes are now measured, and all the scientific ways in which cardiac output as well as arterial and venous pressures can be estimated, the teaching of theory (on this aspect, anyhow) is somewhat divorced from practice. If that is the aim of the book, well and good-but then the authors' opinions on the clinical implications of such a practical subject as preparation of the breasts for lactation should have been omitted, and that would have been a shame.

Among many particulars fascinating details are the incidence of multiple births in different countries of the world; the role of Prochownick (of whom I confess I had never heard before) who in 1889 first propounded the idea of a high protein, low carbohydrate, low fluid diet, and later designed diets for three different groups of women; and, in the section on the alimentary tract, a discussion of pica. Yet, there is hardly any mention of such important clinical matters as vomiting in pregnancy, and but a line or two on the heart sounds and on the transmission of aortic sounds.
This book deserves to reach a second edition, only because it contains about a thousand references and is itself under 500 pages in length. In these pages a distillate of the reading from those thousarid references, and of the results of the authors' own original research, is cleverly presented. It would improved in balance and readability if a clinician arfa a teacher of the English language were consulted during its preparation. Thus somewhat meaningles sentences, such as the last one on page 49, wou be eliminated. Perhaps these criticisms would hat been a little less carping if a group of pages of the book had not dropped out immediately on opening it, and thus prejudiced a little the reviewer? attitude.

As one would expect from Aberdeen it contains much reference to the difference in physiological function among the different social grades of ous society, and this makes it complete and ext valuable as a book of reference.

\section{Viruses, Nucleic Acids and Cancer}

$A$ Collection of Papers Presented at the Severt teenth Annual Symposium on Fundamental Cancer Research at the University of Texas M. W. Anderson Hospital and Tumor Institute. Pp. 659 illustrated. Baltimore: Williams and Wilkinङ. 1964. \$16.00.

This book records the proceedings of the seventeenth annual symposium on fundamental cancer research held at Texas in 1963. As is usual in such books the quality of the work presented is rather uneven and there is a certain amount of repetitiof Readers of the book, provided they have a sooned basic knowledge of the subject, will gain a geod overall picture of the present views of the pree viruses hold in cancer research. The first half of the book deals with fundamental work on virusest consisting of papers on such matters as their structure, methods of replication and properties of viral nucle acid. This part of the book presents an impressive picture of the advances in this field during recent years and of the intensive research taking place throughout the world.

The editors are to be congratulated on havin produced a readable, and well and copiously illuș? trated book. A large number of references are quoted; the practice of printing the title and the source of these in full makes this particularty valuable to workers in this field.

\section{NEW EDITION}

\section{Orthopadic Surgery}

Sir Walter Mercer and R. B. Duthie. 6th Edition. Pp. xii +1031 , illustrated. London $\frac{7}{0}$ Edward Arnold. 1964. 18 8s.

Orthopædics is a difficult subject to read, largelne because it is such a difficult subject to write about systematically, made so by the difficulty of deciding whether to divide the subject under disease or regions The problem is to some extent solved by wide read: ing of the many monographs and other supple mentary textbooks which are available, but there is always a need of an exhaustive work to give the broad picture and fill the gaps. Registrars and Posto graduates frequently ask for advice on this subject and the answer must now be Mercer and Duthiem It is not a perfect book, but it is so much in advance of anything that there has been before. \title{
(1)
}

